\title{
Changes in invertase, sucrose-6-phosphate synthase and UDP-glucose pyrophosphorylase activities, and their relations to reducing sugar content in Japanese processing potato varieties stored at low temperature
}

\author{
Hironaka Kazunori*1, Ishibashi Ken-ichi*1, KoAze Hiroshi*1 \\ Kobayashi Sachinori*1, Mori Motoyuki*2, Tsuda Shogo*2and TAKAdA Akiko*2 \\ * 1 Obihiro University of Agriculture and Veterinary Medicine \\ Inada-cho, Obihiro-shi, Hokkaido 080-8555 \\ * 2 National Agricultural Research Center for Hokkaido Region (NARCH) \\ Memuro-cho, Kasai-gun, Hokkaido 082-0071
}

Invertase, sucrose-6-phosphate synthase (SPS) and UDP-glucose pyrophosphorylase (UGPase) activities of three Japanese processing varieties, differing in susceptibility to low temperature sweetening (susceptibile: Norin-1 ; middle: Toyoshiro; resistant: Hokkai-82), were measured at intervals during storage at $7{ }^{\circ} \mathrm{C}$ in order to investigate the role of the three enzyme activities in reducing sugar accumulation during storage. The susceptible variety dramatically increased the reducing sugar content, and invertase, SPS and UGPase activities during storage, whereas the mid-susceptible and resistant varieties progressively increased them. In the three enzymes, both invertase and SPS activities correlated significantly $(\mathrm{p}<0.01)$ with the reducing sugar content, implying that invertase and SPS may play an important role in the regulation of the reducing sugar accumulation of processing potatoes stored at low temperature. This information may be useful for potato breeders to develop new resistant processing varieties.

(Received Jun. 25, 2004 ; Accepted Jan. 8, 2005)

Sugars accumulate in many plants in the cold, and may act as cryoprotectants ${ }^{1}$. Low temperature sweetening (LTS) has been intensively studied especially in potato tubers ${ }^{2), 3)}$. The ancestors of the modern potato grew in the Andes, where low temperatures may render cryoprotectants useful for survival. However, sugar accumulation is an undesirable trait in the crop plant, because tubers that have been stored at low temperature to delay sprouting are unsuitable for the production of crisps and chips; the reducing sugars that they have accumulated react with amino acids during frying, leading to an unacceptably dark color ${ }^{2}$. The mechanism regulating sugar accumulation in the cold is therefore of ecophysiological and commercial interest ${ }^{4}$.

With respect to the mechanism for LTS, SowoKINos ${ }^{5)}$ suggested that three enzymes, i.e., invertase, sucrose-6-phosphate synthase (SPS) and UDP-glucose pyrophosphorylase (UGPase) are key to the regulation of sugar accumulation. However, this issue remains poorly understood ${ }^{4}$.

Japanese potato farmers, processors and breeders wish to know the role of invertase, SPS and UGPase in sugar accumulation in cold-stored Japanese processing potatoes in order to produce light-colored products. Very limited information is available on the invertase activity of the Japanese fresh-consumption variety of potato (Danshaku) $)^{6)}$. However, there are no studies on changes in invertase, SPS and UGPase activities of the processing potato varieties stored at low temperature. Therefore, this study was carried out to investigate changes in the above three enzyme activities in the processing potato varieties differing in susceptibility to LTS, and whether the three

* 1 E-mail : HIRonAKA Kazunori ; kazuhiro@obihiro.ac.jp, IsHIBASHI Ken-ichi ; ken@obihiro.ac.jp, KoAZE Hiroshi ; koaze @obihiro.ac.jp

* 2 E-mail : MoRI Motoyuki ; mtmori@naro.affrc.go.jp, TsudA Shogo ; stsuda@naro.affrc.go.jp, TAKADA Akiko ; aobara @affrc.go.jp 
enzymes are responsible for the reducing sugar accumulation.

\section{Materials and methods}

\section{Source and tuber storage}

Three processing varieties (Norin- 1 : susceptible; Toyoshiro: mid-susceptible ; and Hokkai-82 : resistant) were used in this study. These three varieties were grown in the $\mathrm{NARCH}$ experiment test fields and harvested in September 1999. After harvesting (the first sampling day), the potatoes were cured for two weeks at $12{ }^{\circ} \mathrm{C}$ and $90 \sim 95 \%$ $\mathrm{RH}$. Thereafter, the potatoes were stored at $7{ }^{\circ} \mathrm{C}$ and $90 \sim 95 \% \mathrm{RH}$. Approximately $150 \mathrm{~g}$ of each variety was used for the experiment.

\section{Sample preparation}

Eight potatoes were selected at random from each cultivar, washed, peeled and diced into approximately $5 \mathrm{~mm}$ cubes.

\section{Sugar}

Sugar was extracted from tubers using the method described by WiLson et al . ${ }^{7)}$. Briefly, 50 grams of potato cubes was homogenized in a Waring blender in $50 \mathrm{~m} \ell$ of distilled water for 150 $\mathrm{sec}$. The homogenate was centrifuged at $1,710 \times \mathrm{g}$ for $5 \mathrm{~min}$ at $4{ }^{\circ} \mathrm{C}$. The supernatant was filtered through Toyo No. 5 filter paper and then analyzed using high-performance liquid chromatography (HPLC) (Model BIP-1 , Nihon Bunko Co.) as described previously ${ }^{8)}$.

\section{Enzyme extraction}

Enzyme extraction and assay were done according to the procedure of Sowokinos et al ${ }^{9)}$. Potato tubers $(25 \mathrm{~g})$ were homogenized in a Waring blender at high speed for $90 \mathrm{sec}$ with $25 \mathrm{~m} \ell$ buffer $(\mathrm{pH}$ 6.3). The suspension was centrifuged at 18,000 $\times \mathrm{g}$ for $15 \mathrm{~min}$ at $4{ }^{\circ} \mathrm{C}$. The precipitate was washed with $20 \mathrm{~m} \boldsymbol{l}$ of the above buffer, recentrifuged, and the two supernatants were combined. The extract was dialyzed overnight against $50 \mathrm{mM}$ Trismaleate ( $\mathrm{pH} 6.3,40$ volumes) with one change. The dialysate was centrifuged to remove inactivated protein.

\section{Invertase (EC 3.2.1.26)}

Invertase activity was assayed as previously described by Sowokinos et al . .) . The reaction mixture ( $1 \mathrm{~m} \ell$ ) contained $0.25 \mathrm{M}$ sucrose, $40 \mathrm{mM}$ trisphosphate $(\mathrm{pH} 6.6), 10 \mathrm{mM} \mathrm{NaF}, 5 \mathrm{mM} 2$ mercaptoethanol, and diluted enzyme extract containing $0.1 \mathrm{mg}$ protein or less. The incubation was carried out at $37^{\circ} \mathrm{C}$ for $30 \mathrm{~min}$, and the amount of reducing sugar liberated was determined by the Somogyi method ${ }^{12)}$. One unit of activity for invertase is defined as that amount of enzyme which liberates $1 \mu \mathrm{mol}$ of glucose/h.

\section{Sucrose-6-P synthase (EC 2.4.1.14)}

Sucrose-6-P synthase extraction and assay were done following the procedure of Sowokinos et al. ${ }^{9)}$. The buffer used to extract sucrose-6-P synthase consisted of a solution of $10 \% \mathrm{NaHSO}_{3}$ and $50 \mathrm{mM}$ Tris-phosphate buffer ( $\mathrm{pH} 7.5,1: 4$ v/v) containing $10 \mathrm{mM}$ GSH and $1 \mathrm{mM}$ EDTA. Extracts were dialyzed against the Tris-phosphate buffer containing $10 \mathrm{mM} \mathrm{NaHSO}$. Reaction mixtures $(0.25 \mathrm{~m} \ell)$ contained $100 \mathrm{mM}$ Tris-phosphate buffer ( $\mathrm{pH} 7.3), 20 \mathrm{mM}$ fructose-6-P, $10 \mathrm{mM}$ UDPglucose, $50 \mathrm{mM} \mathrm{NaF}$, and diluted enzyme containing between 0.02 and 0.2 units of enzyme. Boiled enzyme blanks and sucrose standards $(0.5 \mu \mathrm{mol})$ were run with each assay. After incubation at $37^{\circ} \mathrm{C}$ for $1 \mathrm{hr}, 0.25 \mathrm{~m} \ell$ of $5 \mathrm{~N} \mathrm{NaOH}$ was added to each reaction, which was then placed into a boiling water bath for $10 \mathrm{~min}$ to destroy unreacted fructose-6-P. The concentration of sucrose6 -P was determined by the thiobarbituric acid $\operatorname{method}^{10)}$. One unit of activity is defined as that amount of enzyme which catalyzes the formation of $1 \mu \mathrm{mol}$ of sucrose-6-P/h.

\section{UDPglucose pyrophosphorylase (EC 2. 7. 7.9)}

UDPglucose pyrophosphorylase activity was also assayed using the method of SowoKINos et al ${ }^{9}$. The buffer used to extract and dialyze UDPglucose pyrophospholylase consisted of $50 \mathrm{mM}$ Hepes $(\mathrm{pH}$ 7.5) containing $1 \mathrm{mM}$ EDTA, $2 \mathrm{mM} \mathrm{GSH}$, and $20 \%$ sucrose. The incubation was carried out at 37 ${ }^{\circ} \mathrm{C}$ for $30 \mathrm{~min}$, and the rate of $\alpha$-D-glucose- $1-\mathrm{P}$ pyrophospholysis from UDPglucose was measured spectrophotometrically $(340 \mathrm{~nm})$ in the presence of excess phosphoglucomutase, glucose-6-P dehydrogenase, and NADP. One unit of activity is defined as that amount of enzyme which catalyzes the formation of $1 \mu \mathrm{mol}$ of $\alpha$-D-glucose- 1 -P/h.

All analyses were performed six times, and results were averaged to obtain mean values.

\section{Results and discussion}

Fig. 1 4 show changes in the sugar content of potatoes stored at $7{ }^{\circ} \mathrm{C}$. As shown in Fig. 1, the glucose content of the Norin- 1 potato increased rapidly, whereas that of the Toyoshiro potato increased progressively. However, there was little 


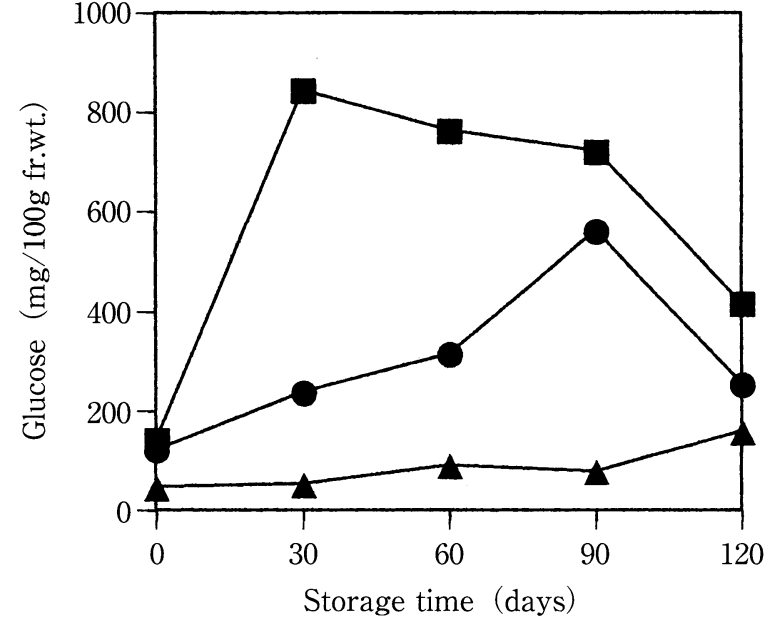

Norin-1

- Toyoshiro

- Hokkai-82

Fig. 1 Changes in glucose content of processing potatoes during storage at $7{ }^{\circ} \mathrm{C}$

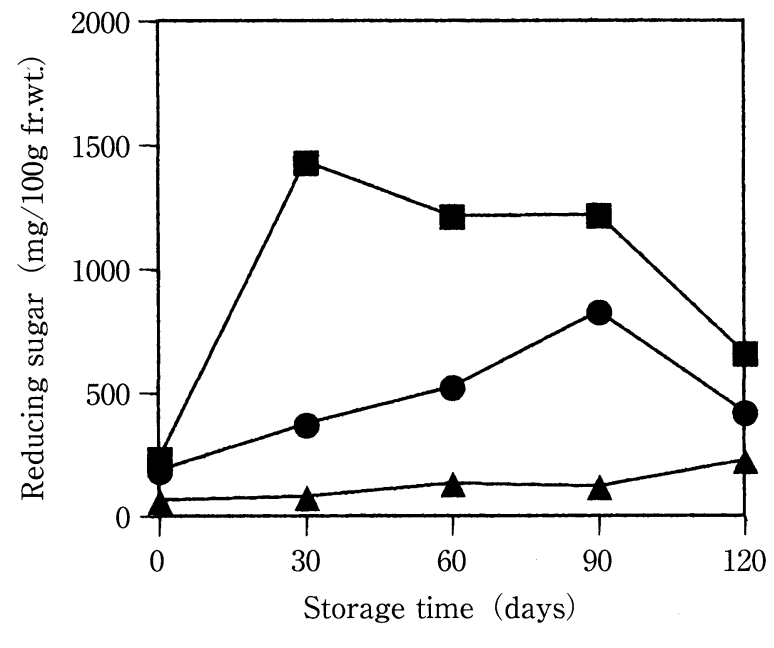

Norin-1

Toyoshiro

- Hokkai-82

Fig. 3 Changes in reducing sugar content of processing potatoes during storage at $7{ }^{\circ} \mathrm{C}$

accumulation for the Hokkai-82 potato. Similarly to the behavior of the glucose content in Fig. 1, the fructose content sharply raised in the Norin- 1 potato, followed by the Toyoshiro and Hokkai- 82 varieties (Fig. 2). With respect to the reducing sugar (glucose+fructose) content, the same behavior was observed as the glucose and fructose contents (Fig. 3). In addition, similar increases in reducing sugar content during storage at low temperatures have been reported for Japanese fresh consumption $^{11) \sim 13)}$ and processing varieties ${ }^{14), 15)}$.

In Fig. 4, sucrose contents of each potato at harvesting time ( 0 day in Fig. 4) were considerably high. Richardson et al ${ }^{16)}$ reported that storage

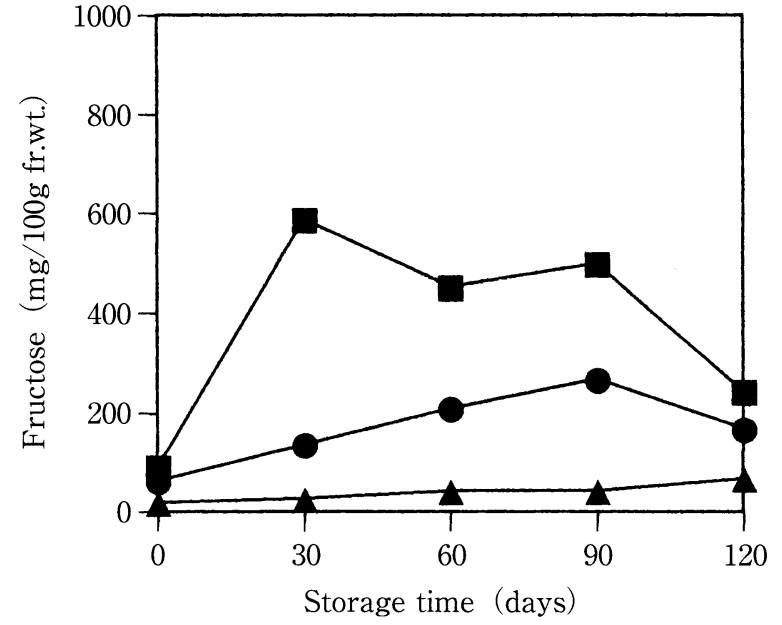

Norin-1

Toyoshiro

Hokkai-82

Fig. 2 Changes in fructose content of processing potatoes during storage at $7{ }^{\circ} \mathrm{C}$

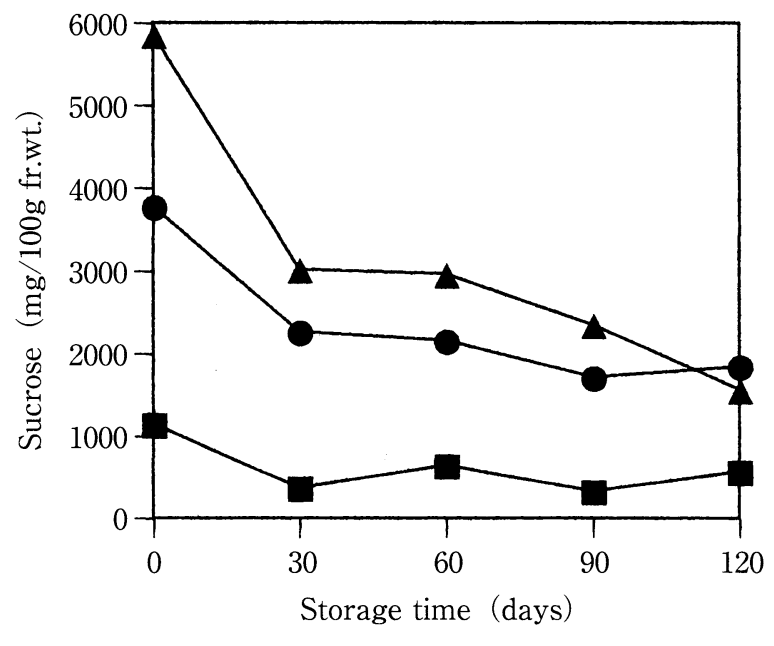

Norin-1

Toyoshiro

Hokkai-82

Fig. 4 Changes in sucrose content of processing potatoes during storage at $7{ }^{\circ} \mathrm{C}$

temperature of $3{ }^{\circ} \mathrm{C}$ rapidly increased sucrose content of potatoes within one week after the start of storage. Then, high contents of sucrose might be caused by low soil temperatures around potato tubers in Obihiro. In addition, DeITING et al ${ }^{17)}$ showed that sucrose content remained almost constant during storage at 11 and $7{ }^{\circ} \mathrm{C}$, whereas that increased rapidly at 5 and $3{ }^{\circ} \mathrm{C}$. Thus, in the present study sucrose contents of each potato decreased gradually during curing at $12^{\circ} \mathrm{C}$ for two weeks and subsequent storage at $7{ }^{\circ} \mathrm{C}$, but each potato maintained comparatively high sucrose content during storage (Fig. 4).

Fig. 5 shows changes in invertase activity at $7{ }^{\circ} \mathrm{C}$. 
As shown in this figure, the invertase activity of the Norin- 1 variety increased sharply, whereas those of the Toyoshiro and Hokkai- 82 varieties increased progressively and slightly, respectively. UPPAL and VERMA ${ }^{18}$ also reported the increase in invertase activity of Indian potato varieties stored at low temperature.

Fig. 6 shows changes in SPS activity at $7{ }^{\circ} \mathrm{C}$. The susceptible variety (Norin- 1 potato) rapidly increased the activity, whereas the other varieties, midsusceptible (Toyoshiro) and resistant (Hokkai-82) potatoes, increased gradually. The rise in SPS activity of potatoes stored at low temperatures has been reported by PRESSEY ${ }^{19)}$ and Deiting et al. ${ }^{17)}$.

Fig. 7 shows changes in UGPase activity at $7{ }^{\circ} \mathrm{C}$. As shown in this figure, the UGPase activity of the Norin- 1 potato increased gradually, while that of the Toyoshiro variety decreased at the beginning of storage, and later increased. A similar rapid decrease in UGPase activity during storage at low temperature has been reported in a low sugar variety ${ }^{20)}$.

Concerning starch degradation in potato tubers, the starch is thought to be degraded via a mainly phosphorolytic route, based on the relative activities of phosphorylase and amylolytic enzymes in the tuber $^{3)}$, and on comparison of the rates of respiration, the rate of sugar accumulation, and the energetic requirements of the different routes for the conversion of starch to sucrose ${ }^{21)}$. The hexose phosphates are then exported to the cytosol via a phosphate translocator that accepts hexosephosphates ${ }^{22}$, and are converted to sucrose via UGPase, followed by SPS $^{23)}$. UGPase produces the cytosolic intermediate UDP-glucose, which is a substrate for SPS reaction (sucrose synthesis) ${ }^{24)}$. Thereafter, the sucrose can subsequently be hydrolysed to glucose and fructose by acid invertase $e^{25}$.

In order to investigate whether the three enzymes in the present study (invertase, SPS and UGPase) contribute to the accumulation of reducing sugar content, we attempted to examine correlations between reducing sugar content and the three enzyme activities. Table 1 gives the results, in which the invertase and SPS activity correlated significantly $(p<0.01)$ with the reducing sugar content, implying that invertase and SPS play an important role in the regulation of reducing sugar accumulation of processing potatoes stored at low

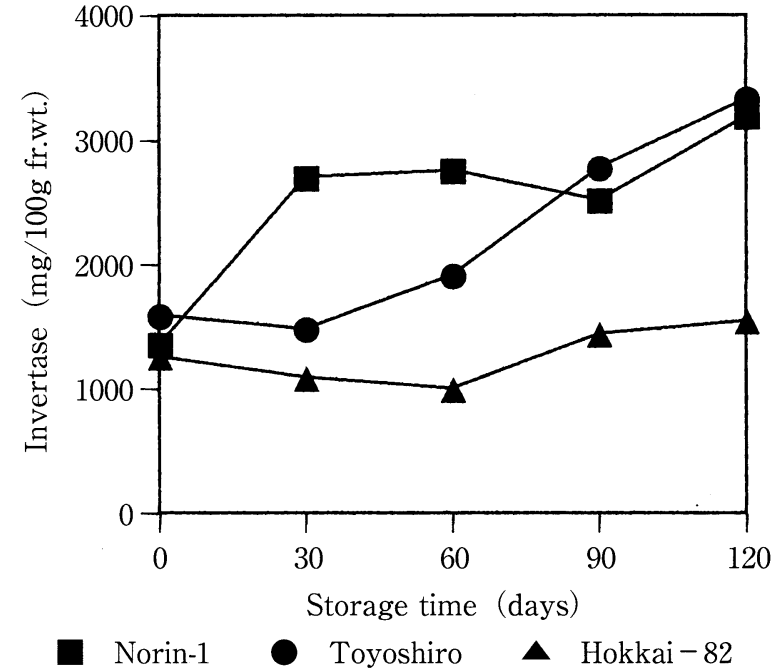

Fig. 5 Changes in invertase activity of processing potatoes during storage at $7{ }^{\circ} \mathrm{C}$

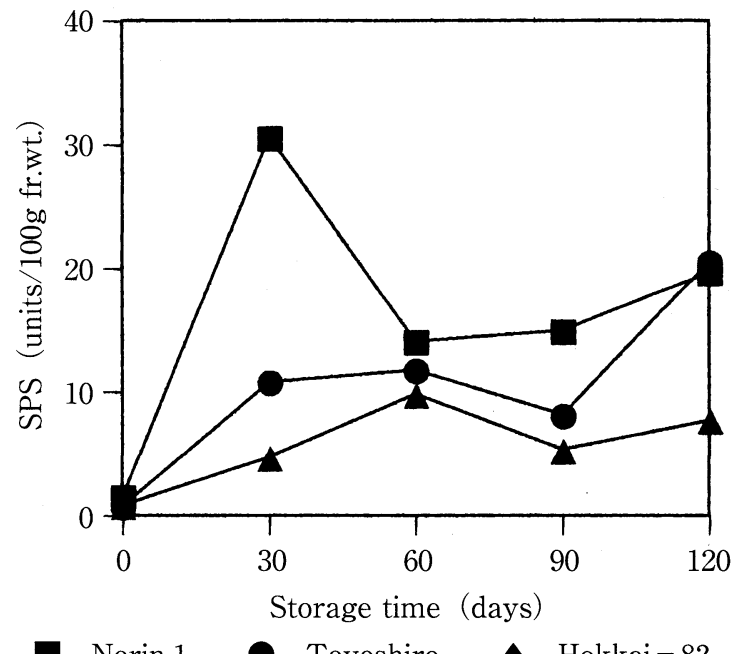

Fig. 6 Changes in SPS activity of processing potatoes during storage at $7{ }^{\circ} \mathrm{C}$

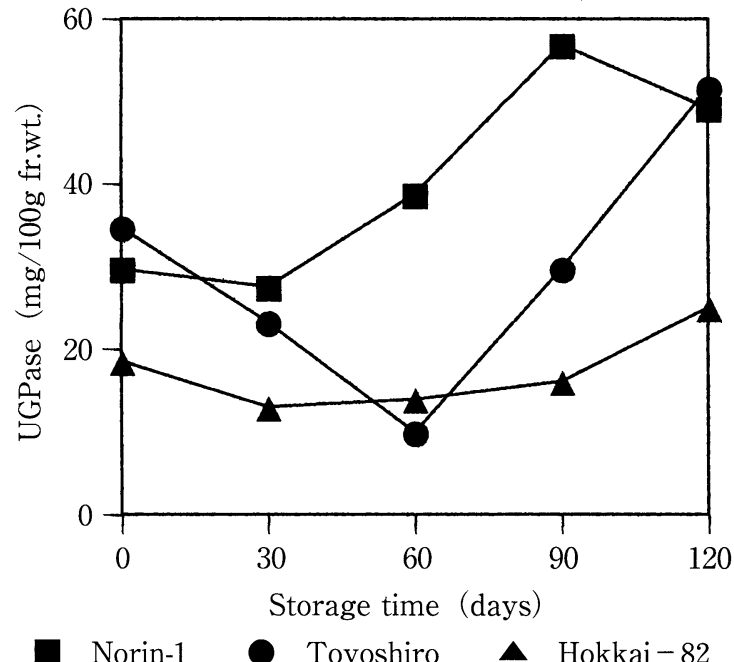

Fig. 7 Changes in UGPase activity of processing potatoes during storage at $7{ }^{\circ} \mathrm{C}$ 
Table 1 Correlation between reducing sugar content and three enzymes in processing potato tubers during storage

\begin{tabular}{lc}
\hline Enzyme & Correlation coefficient \\
\hline Invertase & $0.720^{*}$ \\
SPS & $0.740^{*}$ \\
UGPaes & 0.515 \\
\hline
\end{tabular}

*significant at $\mathrm{P}=0.01$

temperature. This information may be useful for potato breeders to develop new resistant processing varieties.

\section{Conclusion}

The results of the present study demonstrated that invertase and SPS may play an important role in the regulation of reducing sugar accumulation in Japanese processing potatoes stored at low temperature.

\section{References}

1 ) Guy, C.L.: Cold acclimation and freezing stress tolerance. Role of protein metabolism, Annual Review of Plant Physiology and Plant Molecular Biology, 41, 187 223 (1990)

2 ) Burton, W. G.: The Potato, 3 rd ed. (Longman Scientific \& Technical, London), pp.395 422 (1989)

3 ) Davies, H.V. and Viola, R.: regulation of sugar accumulation in stored potato tubers, Post-harvest News and information, 3, 97 N 100 N (1992)

4 ) Hill, L. M., Reimholz, R., Schroder, R., Nielsen, T.H. and Stiтt, M.: The onset of sucrose accumulation in cold-stored potato tubers is caused by an increased rate of sucrose synthesis and coincides with low levels of hexose-phosphates, an activation of sucrose phosphate synthase and the appearance of a new form of amylase, Plant, Cell and Environment, 19, 1223 1237 (1996)

5 ) Sowokinos, J.R.: Effect of stress and senescence on carbon partitioning in stored potatoes. Amer. Potato J., 67, 849 857 (1990)

6 ) Murata, Y., Noguchi, T., Kevin, F.Y., Sato, H., Matsumoto, S., Takano, K. and Suzuki, T.: Amylase and invertase activity and substrate affinity in 'Danshaku' potato tubers (Solanum tuberosum L.) during cold storage, Food Preser. Sci., 26, $281 \sim 287 \quad(2000)$

7 ) Wilson, A.M., Work, T.M., Bushway, A.A. and
Bushway, R.J.: HPLC determination of fructose, glucose and sucrose in potatoes, J. Food Sci., 46, 300 301 (1981)

8 ) Hironaka, K., Takada, K. and Ishibashi, K.: Chemical composition of mucilage of Chinese yam, Nippon Shokuhin Kogyo Gakkaishi, 37, 48 51 (1990)

9 ) Sowokinos, J.R., Lulai, E.C. and Knoper, J.A.: Translucent tissue defects in Solunum Tuberosum L., Plant Physiol., 78, 489 494 (1985).

10) Percheron, F. : Dosage colorime'trique du fructose et des fructofuranosides par l'acide thiobarbiturique. Comptes Rendus de l'Academie des Science, 255, 2521 2522（1962）

11) Kevin, F.Y., Sato, H., Suzuki, T., Takano, K. and KozImA, T.: Sugar accumulation as a mechanism for freezing tolerance in cold-stored 'Danshaku' potato tuber (Solanum tuberosum L.), Food Preser. Sci., 26, 103 107 (2000)

12) Murata, Y., Kevin, F.Y., Noguchi, T., Suzuki, T., Sato, H., Matsumoto, S. and Takano, K.: Properties changes in potato tubers (Solanum tuberosum L.) during cold storage at 0 and $10^{\circ} \mathrm{C}$, Food Preser. Sci., 26, 153 160 (2000)

13) Murata, Y., Noguchi, T., Kevin, F.Y., Sato, H., Matsumoto, S., Takano, K. and Suzuki, T.: Amylase and invertase activity and substrate affinity in 'Danshaku' potato tuber (Solanum tuberosum L.) during cold storage, Food Preser. Sci., 26, 281 287 (2000)

14) Hironaka, K., Ishibashi, K., Minami, M. and KoAze, H.: Unequal distribution of sugar and starch contents within Japanese processing potatoes during storage, Food Preser. Sci., 27, 331 338 (2001)

15) Hironaka, K., Ishibashi, K., Minami, M. and KoAze, H.: Sugar and starch contents of processing potatoes during reconditioning, Food Preser. Sci., 29, 95 100 (2003)

16) Richardson, D. L., Davies, H. V., Ross, H. A. and MACKAY, G.R.: Invertase activity and its relation to hexose accumulation in potato tubers, J. Experi. Botany, 41, 222, 95 99 (1990)

17) Deiting, U., ZRenner, R. and Stitt, M.: Similar temperature requirement for sugar accumulation and for the induction of new forms of sucrose phosphate synthase and amylase in cold-stored potato tubers, Plant, Cell and Environment, 21, 127 138 (1998)

18) Uppal and Verma: Changes in sugar content 
and invertase activity in tubers of some Indian potato varieties stored at low temperature, Potato Res., 33, 119 123 (1990)

19) Pressey, R.: Changes in sucrose synthetase and sucrose phosphate synthetase activities during storage of potatoes, Amer. Potato J., 47, 245 251 (1970)

20) Sowokinos, J.: Post-harvest regulation of sucrose accumulation in transgenic potatoes. Role and properties of potato tuber UDP-glucose pyrophosphorylase, in The Molecular and Cellular Biology of the Potato, 2 nd ed. (BelknAP, W. R., VAYDA, M. E. and PARK, W. D., ed.) (CAB International, UK), p. 88 (1994)

21) IsHerwood, R.J.: Starch-sucrose interconversion in Solanum tuberosum, Phytochemistry, 12, 2579 2591 (1973)

22) Schott, K., Borchert, S., Muller-rober, B. and HELDT, H. W.: Transport of inorganic phosphate and C3-and C6-sugar phosphates across the envelope membranes of potato tuber amyloplasts, Planta, 196, 647〜652 (1995)

23) Pollock, C. J. and ap ReEs, T.: Activities of enzymes of sugar metabolism in cold-stored tubers of Solanum tuberosum, Phytochemistry, 14, 613 $\sim 617$ (1975)

24) Sowokinos, J. R.: Stress-induced alterations in carbohydrate metabolism, in Molecular and Cellular Biology of the Potato (VAYDA, M. and PARK,W., ed.) (CAB International, UK), pp.137 158
(1990)

25) Zrenner, R., Schuler, K. and Sonnewald, U. : (1996) Soluble acid invertase determines the hexose to sucrose ratio in cold-stored tubers, Planta, 198, 246 252 (1995)

\section{低温貯蔵加エ用ジャガイモのインベルターゼ, スクロースー6-リン酸シンターゼおよび \\ UDP-グルコースピロホスホリラーゼ活性の推移と それらの酵素の還元糖含量との関係}

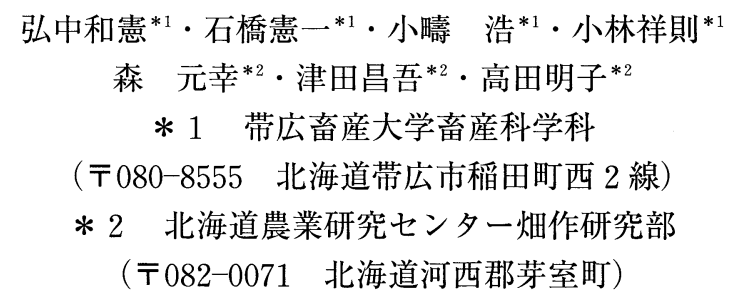

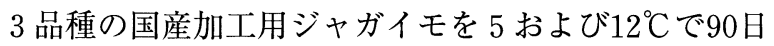
間貯蔵し，インベルターゼ，スクロース-6-リン酸シン ターゼ（SPS）およびUDP-グルコースピロホスホリラ ーゼ（UGPase）活性を測定した。この研究の目的は, それらの 3 酵素に及ぼす貯蔵温度の影響の検討である。 $5{ }^{\circ} \mathrm{C}$ 貯蔵のジャガイモは $12^{\circ} \mathrm{C} に$ 比べ多くの還元糖を蓄積 した。さらに，低温 $\left(5^{\circ} \mathrm{C}\right)$ はインベルターゼおよびSPS は活性を増加させた。これらのことより, 加工用ジャガ イモの低温における還元糖増加に，この 2 つ酵素は重 要な役割をになっているものと推察された。

(平成 16 年 6 月 25 日受付, 平成 17 年 1 月 8 日受理) 